\title{
Splenunculus can mimic acute abdomen: Its clinical and surgical
} relevance

\author{
Arundhati Kar ${ }^{1}$, Praveen Kumar R ${ }^{1}$, Swagatika Samal ${ }^{2}$, Manisha R Gaikwad *1. \\ ${ }^{1}$ Department of Anatomy, ${ }^{2}$ Department of Pathology. \\ All India Institute of Medical Sciences, Bhubaneswar, Odisha- 751019, India.
}

\section{ABSTRACT}

Congenital accessory spleen or splenunculi is a small mass of splenic tissue that failed to fuse with the primary spleen during embryogenesis. The overall prevalence of splenunculus in $14.5 \%$ in the literature. Splenunculus is usually asymptomatic in most of the individuals and diagnosed incidentally during the abdominal imaging, laparotomy or necropsy. Rarely it might present as an acute abdomen in case of torsion or infract. Few cases of malignant changes in the accessory spleen are also reported. Surgeons need to be aware of such small masses of splenic tissue during splenectomy, if they are left unnoticed after total splenectomy, it may lead to the recurrence of hematological disorders. In the present case report, the authors described an isolated, solitary splenunculus in a 55 years old male cadaver found during dissection.

KEY WORDS: Accessory spleen, Splenunculi, Splenectomy, Splenosis, Torsion.

Corresponding Author: Dr Manisha R Gaikwad, Department of Anatomy, All India Institute of Medical Sciences, Bhubaneswar, Odisha- 751019. India. Tel: +91 9438884040

E-Mail: anat_manisha@aiimsbhubaneswar.edu.in

Access this Article online

Quick Response code

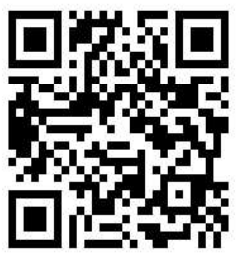

DOI: 10.16965/ijar.2020.245

\begin{tabular}{|c|c|c|}
\hline \multicolumn{3}{|c|}{ Journal Information } \\
\hline \multicolumn{3}{|c|}{$\begin{array}{l}\text { International Journal of Anatomy and Research } \\
\text { ISSN (E) 2321-4287 | ISSN (P) 2321-8967 } \\
\text { https://www.ijmhr.org/ijar.htm } \\
\text { DOI-Prefix: https://dx.doi.org/10.16965/ijar }\end{array}$} \\
\hline \multicolumn{3}{|c|}{ Article Information } \\
\hline $\begin{array}{l}\text { Received: } 13 \text { Nov } 2020 \\
\text { Peer Review: } 13 \text { Nov } 2020 \\
\text { Revised: None }\end{array}$ & $\begin{array}{l}\text { Accepted: } 29 \text { Dec } \\
\text { Published (O): } 30 \\
\text { Published (P): } 05\end{array}$ & $\begin{array}{l}20 \\
2020 \\
2020\end{array}$ \\
\hline
\end{tabular}

\section{INTRODUCTION}

Congenital variations of the spleen, including persistent lobulation, multilobulated spleen, ectopic spleen, asplenia, polysplenia, splenunculi and spleno-gonadal fusion are reported frequently in the literature [1].

Congenital accessory spleen or splenunculi are ectopic splenic tissue separated from the main splenic tissue around the fifth week of embryogenesis[2]. The acquired form of the accessory spleen or splenosis is due to the seeding of injured splenic tissue into nearby structures[3,4]. It is essential to be aware of such small masses of splenic tissue during splenectomy, as it may lead to the recurrence of the hematological disorder[2]. These accessory splenic tissues are important as they may mimic as acute abdomen due to torsion/ infarction of spleen $[5,6]$. In this case report, authors discuss a case of isolated, solitary splenunculus in an adult male Indian cadaver with its histological and immunohistochemical features.

\section{CASE REPORT}

During the routine dissection of abdominal organs for undergraduate medical students, the authors found an isolated, solitary accessory splenic tissue in a 55 years-old-adult male Indian cadaver. Further dissection was done to demonstrate its detailed anatomy, location and blood supply. The normal spleen was located in the left hypochondriac region, which was supplied by the splenic artery. A small solitary mass of splenic tissue (splenun- 


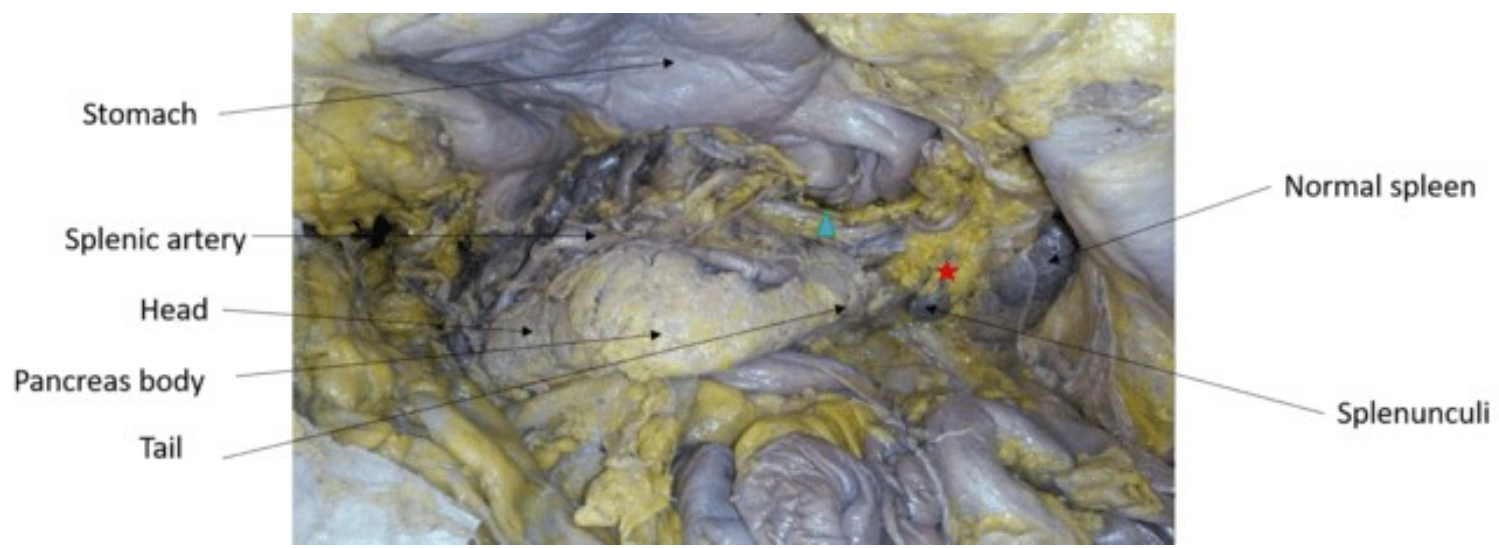

Fig. 1: In the dissected cadaver after reflecting the stomach,the normal spleen in left upper quadrant of the abdomen receiving the blood supply from splenic artery and Pancreas seen in relation to the splenic artery and a splenunculi $(*)$ lying anteromedial to the normally located spleen.

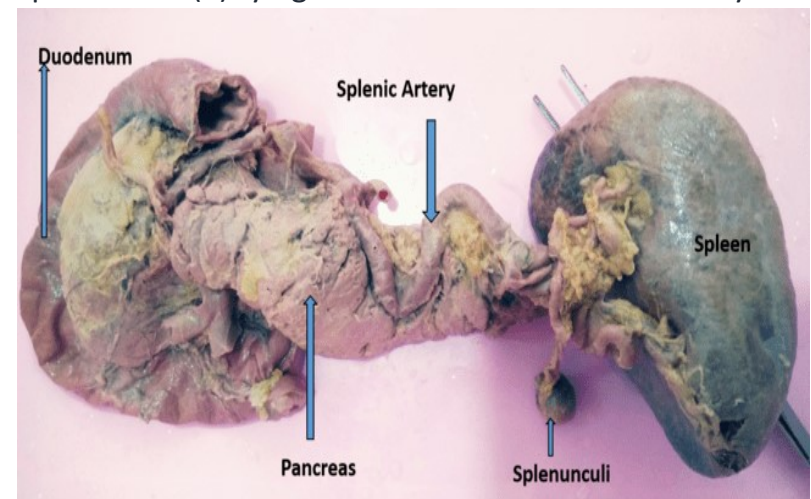

Fig. 2: Specimen showing the C-shaped duodenum with pancreas and normal spleen.The splenic artery along with the vascular pedicle supplying the splenunculi.

culus) measuring about $1 \times 1.5 \times 1 \mathrm{~cm}$, was present in the gastrosplenic ligament. (Fig.1). Splenunculus was located anteromedial to the lower pole of the spleen. The vascular pedicle was identified connecting the accessory spleen to the splenic artery (Fig. 2). No other variation was noted in this cadaver related to branches of the celiac trunk.

On the naked eye examination, it appeared to have the same gross appearance as that of the normal spleen. However, we confirmed the solitary mass as splenunculus by histological

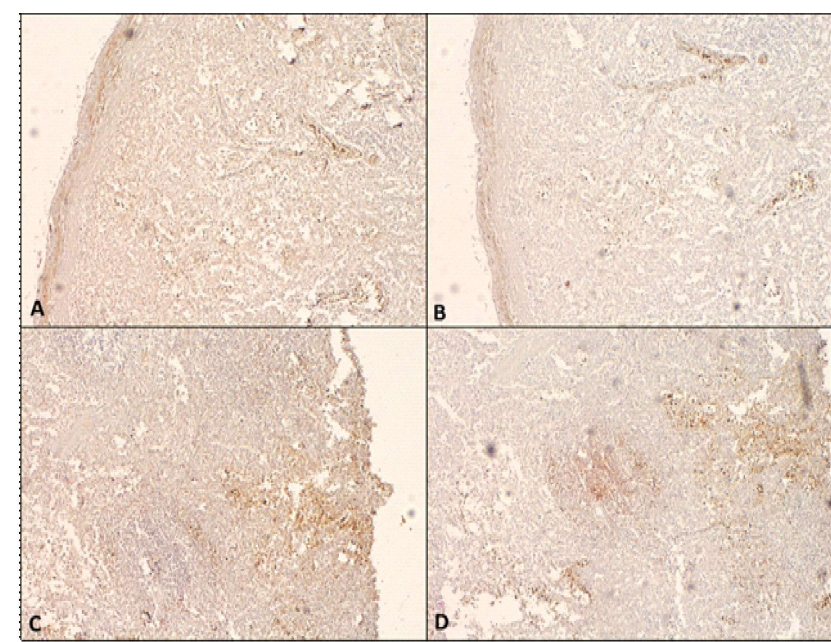

Int J Anat Res 2021, 9(1.1):7861-64. ISSN 2321-4287

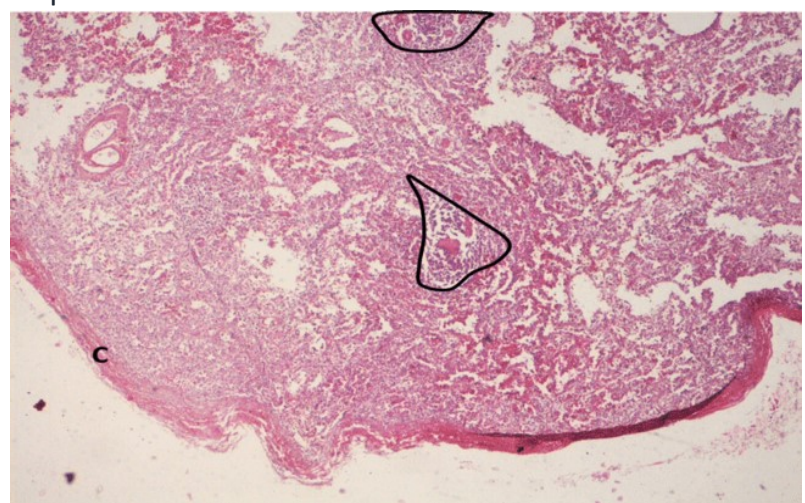

Fig. 3: H\&E image shows the capsule (C) around the tissue. The lymphoid aggregation around an arteriole is similar to the white pulp of the spleen. The surrounding background shows the scattered lymphoid and other blood cells which is the features of the splenic red pulp.

and immunohistochemical (IHC) examination (Fig. 3 \& 4). Hematoxylin and Eosin staining of the tissues revealed the encapsulated lymphoid tissue having characteristic prominent red and white pulp with central arteriole. Tissue was immunoreactive for CD30, CD 20 and $B C L 2$, which are specific for activated $T$ and $B$ cells of white pulp or peri-arteriolar lymphoid sheath of the spleen.

Fig. 4: Photomicrograph of IHC staining. A\&C) Stained with CD30 antibody, which are specific for activated $T$ and $B$ cells; Thus, dense positive area represents the white pulp or Peri-Arteriolar Lymphoid Sheath (PALS) and also shows diffuse positivity in the red pulp of the spleen. B) Stained with BCL2 antibody which is specific for B lymphocyte in mantel or marginal zone and also stains T cells. D) Stained with CD20 antibody, specific for human $B$ cells which stained the white pulp. Hence, we confirmed this tissue as splenic tissue based on the features of H\&E and IHC. 


\section{DISCUSSION}

Splenunculi is usually single or less than six solitary nodular mass adjacent to splenic hilum, which is asymptomatic and detected as an incidental finding during abdominal imaging, surgeries or necropsy[7]. Its incidence in the literature varying widely, a recent meta-analysis study reported an overall

prevalence of $14.5 \%$, out of which imaging studies reported maximum cases (16.6\%) when compared with cadaveric studies (9.1\%) [1]. Most of the studies reported a single accessory spleen (80.4\%). The incidence of more than three accessory spleens is reported in $3.4 \%$ of cases only. The accessory spleen is frequently reported in females than males[1].

The accessory spleen is most frequently located in splenic hilum (62.1\%), followed by tail of the pancreas, greater omentum, along the splenic artery, gastrosplenic ligament, gastrocolic ligament and splenocolic ligament[1]. In the present case, the accessory spleen was observed in the gastrosplenic ligament, which is a relatively rare presentation (3\%). Even with modern-day imaging techniques, the diagnosis of the accessory spleen or splenunculus is challenging[6]. Splenosis was ruled out based on the histology findings as a well-formed capsule, trabeculae and central arterioles were seen in the areas of white pulp, which are characteristic features of splenunculi and the same are absent in splenosis[3,4]. On the other hand, splenosis is an acquired condition occurring after splenectomy or after splenic rupture when the encapsulated splenic tissue is disseminated in the peritoneal cavity and this receives its blood supply by way of neovascularity at the site of implantation.

Embryogenesis of the spleen occurs around the end of the fifth week of gestation by the migration of angiogenetic mesenchymal cells into the thickened coelomic epithelium of the dorsal mesogastrium $[8,9]$. This process of splenic tissue formation occurs simultaneously as various small vacuoles around the caudal end of the dorsal mesogastrium[8]. Finally, all the adjacent small vacuoles join to form lobulated spleen; later on, it gives the characteristic adult appearance of the spleen. If there is any detachment of splenic tissue or failure of fusion of splenic vesicle to main splenic tissue results in the formation of accessory spleen or polysplenia[7]. Rarely splenic tissue gets embedded into surrounding developing organ resulting in ectopic spleen inside the other organs like the pancreas, mesentery etc [10-12].

Even though splenunculus is clinically asymptomatic in most of the cases, it is seen more often in patients with idiopathic thrombocytopenic purpura or immune thrombocytopenia[1]. The presence of splenunculus is beneficial as if the splenectomy is done due to splenic injury, splenunculus will enlarge and takeover the most of its function. On the other hand, if it is missed in cases where splenectomy is done for the therapeutic purpose, it may lead to the recurrence of the disease and requiring a second surgery $[2,13]$. Rarely it may go for torsion, infarct or malignancy, which requires detailed knowledge about these variations for the diagnosis[10]. Splenunculus can be diagnosed with the help of ultrasonography or CT abdomen, but it may resemble as a tumor, enlarged lymph node or metastasis[14]. Tc 99m labeled radionuclide scan can be used to detect smaller splenunculus, but the hepatic uptake of technetium might obscure the splenunculus in the upper abdomen[2,11].

\section{CONCLUSION}

The accessory spleen occurrence is relatively higher in the population. Torsion or malignancy of accessory spleen is a rare presentation that should be kept in mind in cases of acute upper abdominal pain. Splenunculus is better to be preserved during splenectomy if done to treat splenic rupture; but it should be removed in cases of hematological or immunological disorders. Knowledge of detailed anatomy of the accessory spleen is essential for the clinician, surgeons and radiologist for proper diagnosis and planning of the surgery.

\section{Conflicts of Interests: None}

\section{REFERENCES}

[1]. Vikse J, Sanna B, Henry BM, Taterra D, Sanna S, Pêkala PA: The prevalence and morphometry of an accessory spleen: A meta-analysis and systematic review of 22,487 patients. Intl. J. Surg. 2017;45:18-28. 
[2]. Govindaraj S, Roshini AP: Incidence and implications of spleniculi: a five-year experience. Intl. Surg. J. 2018;6:98.

[3]. Mohan H: Splenunculi-Report of Three Cases Splenunculi- Report of Three Cases. 2015;1-4. http:// medind.nic.in/jae/t02/i1/jaet02i1p70.pdf

[4]. Palumbo V, Mannino M, Teodoro M, Menconi G, Schembari E, Corsale G: An extremely rare case of an oversized accessory spleen: Case report and review of the literature. BMC Surg. 2019;19:1-7.

[5]. Goodman P, Raval B, King FA: Spontaneous necrosis and hemorrhage in an enlarged accessory spleen: CT demonstration. Comput. Med. Imaging Graph. 1990;14:201-3.

[6]. Impellizzeri P, Montalto AS, Borruto FA, Antonuccio $P$, Scalfari G, Arena F: Accessory spleen torsion: rare cause of acute abdomen in children and review of literature. J. Pediatr. Surg. 2009;44:e15-8.

[7]. Varga I, Babala J, Kachlik D: Anatomic variations of the spleen: current state of terminology, classification, and embryological background. Surg. Radiol. Anat.2018;40:21-9.

[8]. Sadler TW:Langman's medical embryology. 13th ed. Philadelphia, PA: Wolters Kluwer; 2016. https:// www.ncbi.nlm.nih.gov/nlmcatalog/101562744
[9]. Datta A: Essential of Human Embryology. 7th ed. Kolkata: Current Books International; 2014.

[10]. Luo J, Chen J, Huang F, Zhou P, Huang P: Heterotopic accessory spleen with squamous epithelial cyst in pancreas mimicking other pancreatic tumor: a case report. Ann. Transl. Med. 2020;8:507-507.

[11]. Kawamoto S, Johnson PT, Hall H, Cameron JL, Hruban $\mathrm{RH}$, Fishman EK: Intrapancreatic accessory spleen: CT appearance and differential diagnosis. Abdom. Imaging 2012; 37:812-27.

[12]. De Moura Diógenis Barbosa, Rocha Lara Valeska de Medeiros, Da Silva João Luís Gomes, Júnior EusamarMagalhães, Rocha LauandaÊnia de Medeiros, WanderleyNeto Antonio Bizerra: Giant accessory spleen and rotating ectopic kidney: A rare association. World J. Adv. Res. Rev. 2020;5:026-33.

[13]. Merchant RH, Shah AR, Ahmad J, Karnik A, Rai N: Post Splenectomy Outcome in â-Thalassemia. Indian J. Pediatr. 2015;82:1097-100.

[14]. Herneth AM, Pokieser P, Philipp MO, Bader TR, Helbich TH, Mallek R: Role of Doppler sonography in the evaluation of accessory spleens after splenectomy. J. Ultrasound Med. 2001;20:1347-51.

How to cite this article:

Arundhati Kar, Praveen Kumar R, Swagatika Samal, Manisha R Gaikwad. Splenunculus Can Mimic Acute Abdomen: Its Clinical and Surgical Relevance. Int J Anat Res 2021;9(1.1):7861-7864. DOI: 10.16965/ijar.2020.245 